\title{
INFLUENCE OF N SPLIT APPLICATION ON NH VOLATILIZATION LOSSES AND N RECOVERY EFFICIENCY FROM PLASTIC MULCHING MAIZE IN LOESS PLATEAU, CHINA
}

\author{
WANG, S. J. ${ }^{1}-$ LUO, S. S. ${ }^{2}-$ GAO, Q. $.^{*}-$ LI, S. Q..$^{3 *}$ \\ ${ }^{1}$ College of Resource and Environment, Key Laboratory of Soil Resource Sustainable \\ Utilization for Jilin Province Commodity Grain Bases, Jilin Agricultural University, \\ Changchun 130118, China
}

${ }^{2}$ Key Laboratory of Mollisols Agroecology, Northeast Institute of Geography and Agroecology, Chinese Academy of Sciences, Changchun 130102, China

${ }^{3}$ State Key Laboratory of Soil Erosion and Dryland Farming on the Loess Plateau, Chinese Academy of Sciences and Ministry of Water Resource, Yangling 712100, China

*Corresponding authors

e-mail: gyt199962@163.com; sqli@ms.iswc.ac.cn

(Received 29 $9^{\text {th }}$ Mar 2019; accepted 24 $4^{\text {th }}$ May 2019)

\begin{abstract}
Ammonia $\left(\mathrm{NH}_{3}\right)$ volatilization is one of the main reasons of applied-N loss from agricultural cropping systems. Adjusting the application timing of $\mathrm{N}$ fertilizer to improve temporal synchronicity between crop- $\mathrm{N}$ demand and soil- $\mathrm{N}$ availability could result in higher nitrogen $(\mathrm{N})$ recovery efficiency (NRE) and lower $\mathrm{N}$ losses. A two-year experiment was conducted to investigate the effect of split fertilizer $\mathrm{N}$ application on $\mathrm{NH}_{3}$ volatilization, grain yield, and NRE. Four treatments were included according to the $\mathrm{N}$ application ratio: (i) a single application of total $\mathrm{N}$ fertilizer at sowing (N1), (ii) $\mathrm{N}$ applied with two splits at a ratio of 4:6 (N2), (iii) $\mathrm{N}$ applied with three splits at a ratio of 4:3:3 (N3), and (iv) no $\mathrm{N}$ applied as a control (N0). The results show that $\mathrm{NH}_{3}$ fluxes peaked at 3-5 days after fertilization and then dropped sharply within the next week. $\mathrm{NH}_{3}$ fluxes increased significantly with $\mathrm{N}$ application rate and were significantly and positively correlated with soil $\mathrm{NH}_{4}{ }^{+}-\mathrm{N}$ content. Slight precipitation $(<10 \mathrm{~mm})$ promoted $\mathrm{NH}_{3}$ volatilization, while heavy precipitation (>10 mm) restrained it. Applying $\mathrm{N}$ with two or three splits significantly increased the grain yield, total $\mathrm{N}$ uptake, and NRE of maize and significantly reduced $\mathrm{NH}_{3}$ volatilization losses.
\end{abstract}

Keywords: Dräger-tube method, $N$ application time, $N$ application rate, $N$ loss, grain yield

\section{Introduction}

Ammonia $\left(\mathrm{NH}_{3}\right)$ volatilization is a major pathway of nitrogen $(\mathrm{N})$ losses in agricultural systems worldwide, which results in low fertilizer $\mathrm{N}$ recovery efficiency (NRE) and many other environmental issues, such as soil acidification and surface water eutrophication through $\mathrm{N}$ deposition (Behera et al., 2013). In addition, $\mathrm{NH}_{3}$ is considered a dominant air pollution source, accounting for $25-60 \%$ of the total PM2.5 mass (Sutton et al., 2013), and could become a secondary source of $\mathrm{N}_{2} \mathrm{O}$ (Sutton et al., 2008). Agricultural activities reportedly contribute up to $90 \%$ of the total $\mathrm{NH}_{3}$ emissions to the atmosphere (Boyer et al., 2002), with the majority originating from livestock production and approximately $12 \%$ resulting from $\mathrm{N}$ fertilizer application (Ferm, 1998). An average of $18 \%$ of applied synthetic fertilizer $\mathrm{N}$ is estimated to be lost as $\mathrm{NH}_{3}$ globally (Pan et al., 2016). China is the world's largest $\mathrm{NH}_{3}$ emitter with annual emissions that are 2.7 and 3.0 times higher than those of the European Union and the 
United States, respectively (Paulot et al., 2014). The total $\mathrm{NH}_{3}$ emission of China was estimated to be $3.55 \mathrm{Tg} \mathrm{N}$ in 2005, with an estimated $13.2 \%$ of $\mathrm{N}$ from fertilizer $\mathrm{NH}_{3}$ volatilizing (Zhang et al., 2011). The factors influencing $\mathrm{NH}_{3}$ volatilization include environmental parameters, such as soil $\mathrm{pH}$, moisture, and temperature as well as precipitation (Ma et al., 2010; Yang et al., 2015; Pan et al., 2016) and N fertilizer management practices, such as the use of different types of $\mathrm{N}$ fertilizer, $\mathrm{N}$ rate and application methods (Liu et al., 2015; Yang et al., 2019).

Urea is one of the most widely used $\mathrm{N}$ fertilizers worldwide because of its high $\mathrm{N}$ concentration, and its hydrolysis is known as a key process in inducing $\mathrm{NH}_{3}$ volatilization by producing highly concentrated $\mathrm{NH}_{4}{ }^{+}-\mathrm{N}$ with sharply increased $\mathrm{pH}$ (Black et al., 1987). $\mathrm{NH}_{3}$ volatilization from urea accounts for approximately $10-35 \%$ of the $\mathrm{N}$ applied in field crop planting (Soares et al., 2012). Due to the different demand of plants for $\mathrm{N}$ at different growth stages, surplus nitrogen is a great environmental risk in that it can leach into groundwater or be lost to the atmosphere through $\mathrm{NH}_{3}$ volatilization and denitrification. Thus, adjusting the application timing of $\mathrm{N}$ fertilizer and improving temporal synchronicity between crop-N demand and soil-N availability are key strategies for improving the NRE (Ribaudo et al., 2011). Field experimental data have shown that grain yields, plant $\mathrm{N}$ uptake, and NRE increase with increases in topdressed N fertilizer (López-Bellido et al., 2005; Cui et al., 2008). Scharf et al. (2002) found that crop yields were still responsive to $\mathrm{N}$ application until the silking (R1) stage but that the potential yields were not achieved when $\mathrm{N}$ applications were delayed until that stage. Applying $\mathrm{N}$ with three splits could produce higher grain yields and higher cumulative $\mathrm{N}_{2} \mathrm{O}$ emissions than a single application of $\mathrm{N}$ (Wang et al., 2016). Previous studies have shown that high rates of $\mathrm{N}$ lead to much higher $\mathrm{NH}_{3}$ losses, and the emissions response to increasing $\mathrm{N}$ input is exponential rather than linear (Ma et al., 2010). Therefore, we hypothesize that maintaining a low rate of $\mathrm{N}$ application by using a split application should reduce $\mathrm{NH}_{3}$ volatilization losses.

Plastic mulching is used worldwide in vegetable and grain production, especially in arid, semiarid and subhumid areas (Chen et al., 2014), due to its ability to increase soil temperature and moisture, reduce water evaporation, and improve soil nutrient availability (Li et al., 2004). In addition, as a physical barrier, plastic mulching restricts gas exchange between the soil and atmosphere, thus affecting $\mathrm{NH}_{3}$ volatilization. However, there is little information concerning $\mathrm{NH}_{3}$ volatilization losses from maize under plastic mulching. The objective of this study was to quantify the effect of $\mathrm{N}$ split application on $\mathrm{NH}_{3}$ volatilization, crop yields, and NRE in a plastic mulching maize cropping system on the Loess Plateau of China.

\section{Materials and methods}

\section{Site description}

The field experiment was conducted at Changwu Agricultural and Ecological Experimental Station of Chinese Academy of Sciences $\left(35.28^{\circ} \mathrm{N}, 107.88^{\circ} \mathrm{E}, 1200 \mathrm{~m}\right.$ altitude) in 2014 and 2015, which has a semiarid climate on the Loess Plateau of China. From 2009 to 2013 , the mean annual air temperature is $9.7^{\circ} \mathrm{C}$, and the average annual precipitation is $555 \mathrm{~mm}, 73 \%$ of this falls during the maize growth season (MS), whereas the average potential evaporation is $1560 \mathrm{~mm}$. Total precipitation during MS was $375 \mathrm{~mm}$ in 2014, and $361 \mathrm{~mm}$ in 2015, respectively. The main cropping system in this area includes harvesting one crop of maize or wheat per year. The soil at the 
experiment site is classified as Cumuli-Ustic Isohumosols according to the Chinese Soil Taxonomy (Gong et al., 2007). The soil properties at the top $20 \mathrm{~cm}$ were: bulk density $1.3 \mathrm{~g} \mathrm{~cm}^{-3}, \mathrm{pH} 8.3$, organic $\mathrm{C} 8.1 \mathrm{~g} \mathrm{~kg}^{-1}$, total $\mathrm{N} 1.0 \mathrm{~g} \mathrm{~kg}^{-1}$, available phosphorus (OlsenP) $21.5 \mathrm{mg} \mathrm{kg}^{-1}$, and available potassium $\left(\mathrm{NH}_{4} \mathrm{OAc}-\mathrm{K}\right) 135.2 \mathrm{mg} \mathrm{kg}^{-1}$, and mineral $\mathrm{N}$ $\left(\mathrm{NO}_{3}{ }^{-} \mathrm{N}+\mathrm{NH}_{4}{ }^{+}-\mathrm{N}\right) 28.3 \mathrm{mg} \mathrm{kg}^{-1}$.

\section{Experimental design}

The experimental design consisted of a completely randomized block with three replicates and an area of $5 \mathrm{~m} \times 6 \mathrm{~m}$ for each plot. The split application of $\mathrm{N}$ at the same rate of $225 \mathrm{~kg} \mathrm{ha}^{-1}$ was the major factor that was investigated. The four treatments were (i) no $\mathrm{N}$ as a control (N0), (ii) $100 \% \mathrm{~N}$ applied at sowing (N1), (iii) $\mathrm{N}$ applied at the sowing and jointing (V8) stages in a ratio of 4:6 (N2), and (iv) $\mathrm{N}$ applied at the sowing, V8 and R1 stages in a ratio of 4:3:3 (N3). Half-film mulching was performed for all of the plots; the width of the plastic film and the interval of two films were both $0.5 \mathrm{~m}$, and maize was seeded on both sides of the film, with a row spacing of $0.5 \mathrm{~m}$. For basal $\mathrm{N}, \mathrm{N}$ fertilizer in the form of urea ( $\mathrm{N} \mathrm{46 \% )}$ was manually distributed over the soil surface prior to sowing and then mixed with the soil of the $0-15 \mathrm{~cm}$ layer; for topdressed $\mathrm{N}, \mathrm{N}$ fertilizer was applied in a band in the middle of the no-film rows at a depth of $5 \mathrm{~cm}$. Each plot was supplied with $40 \mathrm{~kg} \mathrm{P} \mathrm{ha}^{-1}$ (calcium superphosphate, $\mathrm{P}_{2} \mathrm{O}_{5}, 12 \%$ ) and $80 \mathrm{~kg} \mathrm{~K} \mathrm{ha}^{-1}$ (potassium sulfate, $\mathrm{K}_{2} \mathrm{O}, 45 \%$ ) at sowing with the base $\mathrm{N}$ fertilizer. A highyielding maize hybrid (Pioneer 335) was used in this study; the plant density was 65,000 plants ha ${ }^{-1}$.

\section{$\mathrm{NH}_{3}$ volatilization measurements}

The calibrated Dräger-Tube method (DTM) was used to quantify $\mathrm{NH}_{3}$ volatilization (Pacholski et al., 2006) as this method has been shown to be well suited for $\mathrm{NH}_{3}$ measurements in multiplot field trials (Ni et al., 2014; Wolf et al., 2014). During the measurement, four stainless steel rings were installed in the upper soil of one plot for each treatment directly after fertilization, 2 on the edge of the mulch, and 2 on the bare land, then they were connected to an $\mathrm{NH}_{3}$ indicator tube and an automatic pump to ensure a defined flow rate. Air was simultaneously sucked through four connected chambers and led through a $\mathrm{NH}_{3}$ tube (Fig. 1). Damaged tubes were exchanged by new tubing. Using Drägertubes for different $\mathrm{NH}_{3}$ concentration ranges allowed measurements of $\mathrm{NH}_{3}$ concentrations ranging from 0.1 to $70 \mathrm{ppm}$. In conjunction with all $\mathrm{NH}_{3}$ measurements, wind speeds at heights of $2.0 \mathrm{~m}$ and $0.2 \mathrm{~m}$ were recorded every $10 \mathrm{~min}$ for the duration of every measuring period (approximately 10-14 days after $\mathrm{N}$ fertilizer application until $\mathrm{NH}_{3}$ volatilization losses were no longer detected), which were used for calculating the calibrated $\mathrm{NH}_{3}$ fluxes.

\section{Soil property measurements}

Soil samples at a $20 \mathrm{~cm}$ depth were taken from each plot for the moisture and $\mathrm{NH}_{4}{ }^{+}-$ $\mathrm{N}$ determinations, while $\mathrm{NH}_{3}$ volatilization was measured using a 4-cm-diameter gauge auger. Each sample was a composite of two subsamples, of which one was taken from the no-mulch bands and the other was taken from film mulched bands, to represent the aggregate condition. The samples were oven-dried at $105^{\circ} \mathrm{C}$ for $24 \mathrm{~h}$ to a consistent weight to determine the gravimetric soil water content, and the soil water-filled pore space (WFPS) was subsequently calculated using Equation 1. To determine the soil 
$\mathrm{NH}_{4}{ }^{+}-\mathrm{N}$ content, representative fresh subsamples $(5 \mathrm{~g})$ were extracted using $50 \mathrm{ml}$ of a $1 \mathrm{~mol} \mathrm{~L}^{-1} \mathrm{KCl}$ solution, and the extracts were analyzed using an automated flow injection analyzer (FLOWSYS, Italy). The soil temperatures at the surface and at a depth of $10 \mathrm{~cm}$ were measured using portable digital thermometers (JM624, Jinming Instrument Ltd., Tianjin, China). Precipitation data were obtained from an automatic weather station near the experimental site.

$$
\text { WFPS }=\frac{\text { Soil water content }(96) \times \text { Soil bulkdensity }}{1-\frac{\text { Soil bulk density }}{2.65}} \times 100 \%
$$

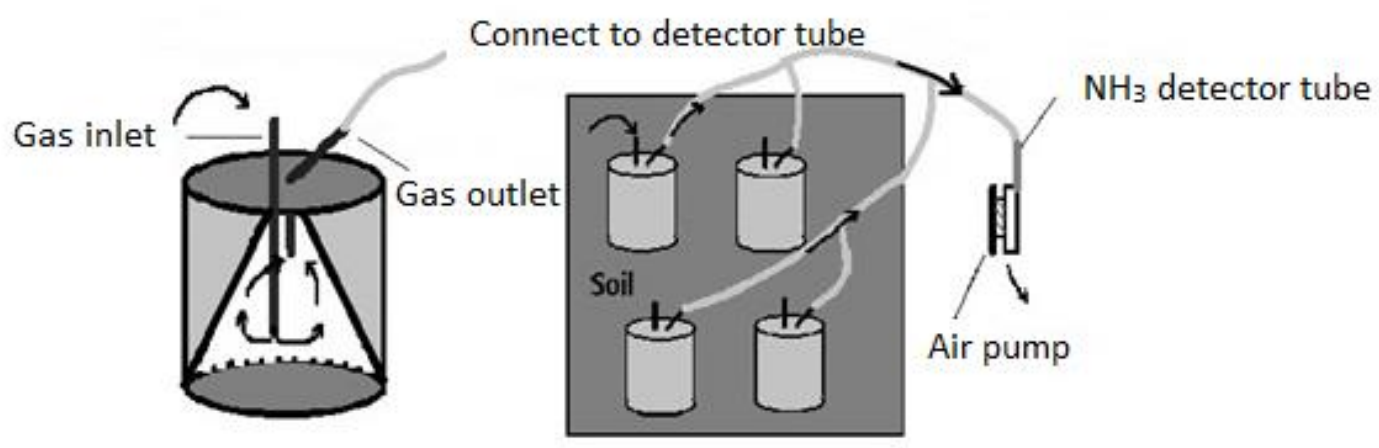

Figure 1. Schematic diagram of $\mathrm{NH}_{3}$ volatilization measurements

\section{Grain yield and $N$ recovery efficiency}

At harvest, $8 \mathrm{~m}^{2}$ (4 rows each $4 \mathrm{~m}$ long) in the middle of each plot was manually harvested to determine the grain yield, and the grain yield was expressed at $15.5 \%$ moisture.

$\mathrm{N}$ recovery efficiency (NRE) was calculated by difference method using Equation 2.

$$
\text { NRE }(\%)=\frac{\text { N uptake in fertilized plot }\left(\mathrm{kg} \mathrm{hm}^{-2}\right)-\mathrm{N} \text { uptake in unfertilized plot }\left(\mathrm{kg} \mathrm{hm}^{-2}\right)}{\mathrm{N} \text { application rates }\left(\mathrm{kg} \mathrm{hm}^{-2}\right)}
$$

\section{Statistical analysis}

Statistical analysis was conducted using the SPSS 20.0 software package for oneway analysis of variance (ANOVA); the statistically significant differences between different treatments were tested by the least significant difference (LSD) at the 5\% level. The Pearson correlation analysis was performed to investigate the correlations between the $\mathrm{NH}_{3}$ volatilization flux and soil variables.

\section{Results}

\section{Soil WFPS, temperature and $\mathrm{NH}_{4}^{+}-\mathrm{N}$ content}

The soil WFPS and temperature during $\mathrm{NH}_{3}$ volatilization measurements over two years are shown in Figure 2. The mean soil temperature during the application of basal $\mathrm{N}$, topdressed $\mathrm{N}$ at the $\mathrm{V} 8$ stage $\left(\mathrm{T}_{\mathrm{V} 8}-\mathrm{N}\right)$ and topdressed $\mathrm{N}$ at the $\mathrm{R} 1$ stage $\left(\mathrm{T}_{\mathrm{R} 1}-\mathrm{N}\right)$ were $15.5^{\circ} \mathrm{C}, 21.3^{\circ} \mathrm{C}$ and $21.7^{\circ} \mathrm{C}$, respectively, in 2014 and were $15.6{ }^{\circ} \mathrm{C}, 18.3^{\circ} \mathrm{C}$ and $18.4^{\circ} \mathrm{C}$, respectively, in 2015 . Soil WFPS fluctuated with precipitation events, varying 
from 20.6 to $59.4 \%$ in 2014 and from 36.7 to $64.4 \%$ in 2015 , and there was no difference among the four treatments.
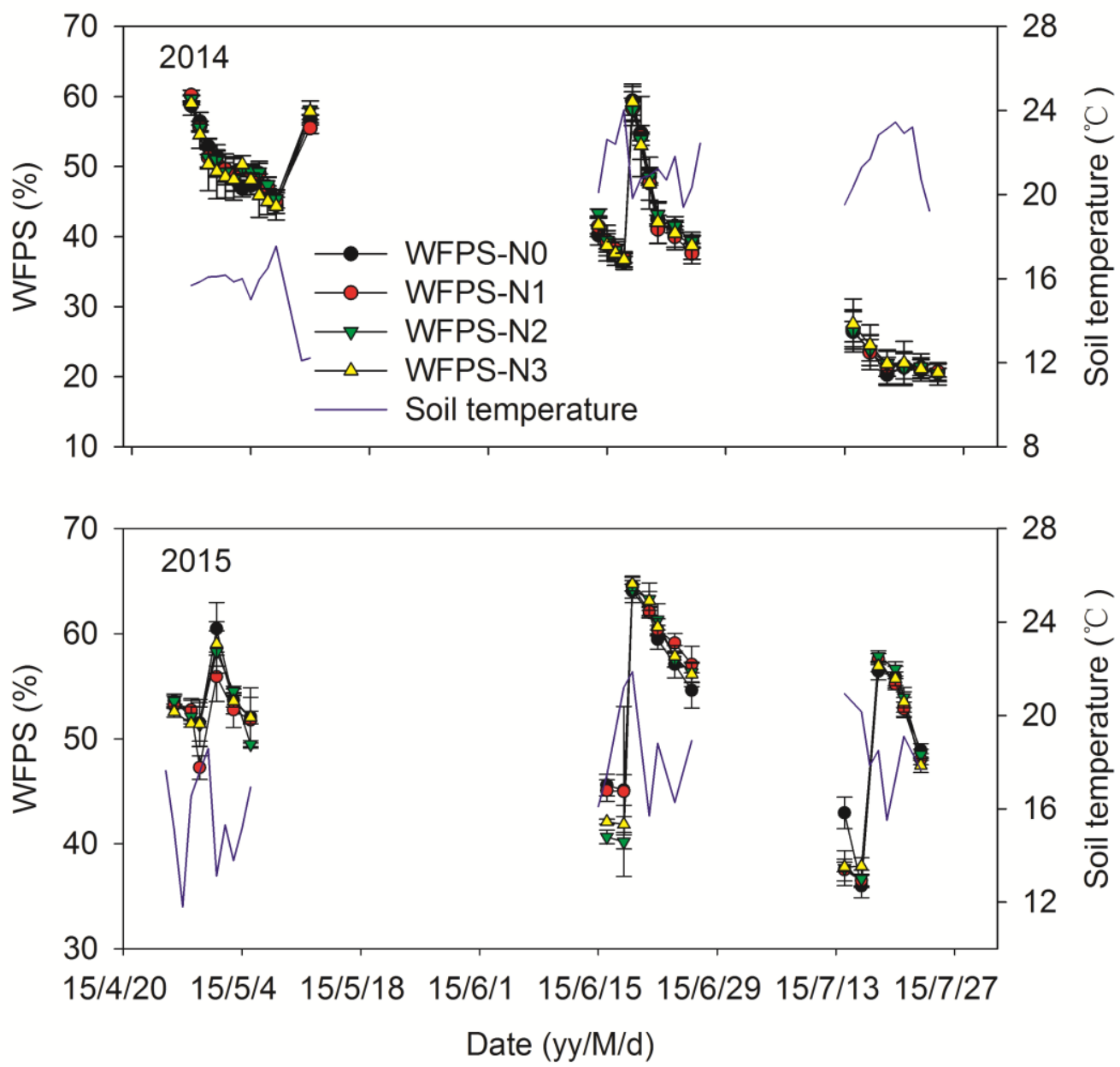

Figure 2. Soil moisture and temperature dynamics during $\mathrm{NH}_{3}$ volatilization measurements in 2014 and 2015

The soil $\mathrm{NH}_{4}{ }^{+}-\mathrm{N}$ content increased sharply after the application of $\mathrm{N}$ fertilizer and then returned to normal within approximately one week (Fig. 3). The mean soil $\mathrm{NH}_{4}{ }^{+}-\mathrm{N}$ content during the basal $\mathrm{N}$ application in the $\mathrm{N} 1$ treatment was $66.1 \mathrm{mg} \mathrm{kg}^{-1}$, which was significantly higher than that in the $\mathrm{N} 2\left(20.7 \mathrm{mg} \mathrm{kg}^{-1}\right)$ and $\mathrm{N} 3\left(17.9 \mathrm{mg} \mathrm{kg}^{-1}\right)$ treatments in 2014. Relatively low soil $\mathrm{NH}_{4}{ }^{+}-\mathrm{N}$ content was measured during basal $\mathrm{N}$ application in 2015, with mean values of 21.6, 5.1 and $4.2 \mathrm{mg} \mathrm{kg}^{-1}$ in the $\mathrm{N} 1, \mathrm{~N} 2$ and $\mathrm{N} 3$ treatments, respectively. After the $\mathrm{T}_{\mathrm{V} 8}-\mathrm{N}$ application, the mean soil $\mathrm{NH}_{4}{ }^{+}-\mathrm{N}$ content was $55.9 \mathrm{mg} \mathrm{kg}^{-1}$ and $26.1 \mathrm{mg} \mathrm{kg}^{-1}$ in treatments $\mathrm{N} 2$ and $\mathrm{N} 3$, respectively, in 2014 and $163.1 \mathrm{mg} \mathrm{kg}^{-1}$ and $77.7 \mathrm{mg} \mathrm{kg}^{-1}$, respectively, in 2015 , respectively. After the $\mathrm{T}_{\mathrm{R} 1}-\mathrm{N}$ application in the $\mathrm{N} 3$ treatment, the mean soil $\mathrm{NH}_{4}{ }^{+}-\mathrm{N}$ content reached $33.2 \mathrm{mg} \mathrm{kg}^{-1}$ and $59.1 \mathrm{mg} \mathrm{kg}^{-1}$ in 2014 and 2015, respectively. Overall, the mean soil $\mathrm{NH}_{4}{ }^{+}-\mathrm{N}$ contents across the whole growth period were 4.2, 28.5, 30.3 and $24.6 \mathrm{mg} \mathrm{kg}^{-1}$ in the N0, N1, N2 and $\mathrm{N} 3$ treatments, respectively, in 2014 and were $1.5,7.4,59.1$ and $49.1 \mathrm{mg} \mathrm{kg}^{-1}$, respectively, in 2015. 

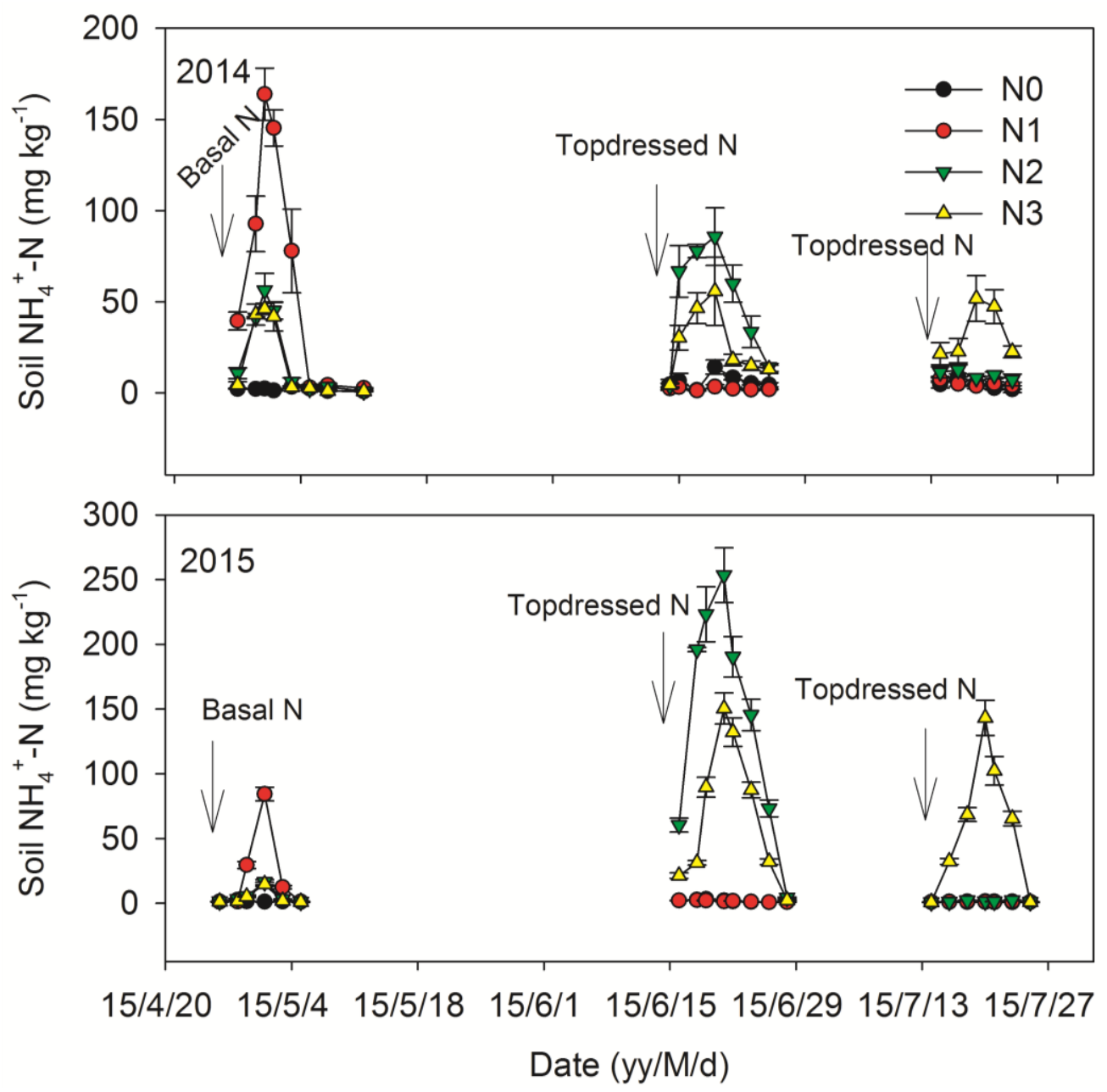

Figure 3. Soil $\mathrm{NH}_{4}{ }^{+}-\mathrm{N}$ dynamics after the application of basal and topdressed $\mathrm{N}$ in 2014 and 2015. Bars denote standard deviations of soil $\mathrm{NH}_{4}{ }^{+}-\mathrm{N}$ content on three replicate plots

\section{$\mathrm{NH}_{3}$ volatilization flux}

The dynamics of $\mathrm{NH}_{3}$ volatilization fluxes with different $\mathrm{N}$ split applications are shown in Figure 4. Since $\mathrm{NH}_{3}$ volatilization mainly occurred after fertilization, it was only determined within two weeks after fertilization in this study. Under different $\mathrm{N}$ application periods, the rate of $\mathrm{NH}_{3}$ volatilization usually peaked at 3-5 days after fertilization and then dropped sharply within the next week. After the basal $\mathrm{N}$ application, the mean $\mathrm{NH}_{3}$ volatilization rate in the two years was $71 \mathrm{~g} \mathrm{ha}^{-1} \mathrm{~h}^{-1}$ in the $\mathrm{N} 1$ treatment, which was significantly higher than the 5, 24, $27 \mathrm{~g} \mathrm{ha}^{-1} \mathrm{~h}^{-1}$ in the $\mathrm{N} 0, \mathrm{~N} 2$ and $\mathrm{N} 3$ treatments, respectively, due to its higher $\mathrm{N}$ application rate. The highest volatilization rates from $\mathrm{N} 1$ were 193 and $234 \mathrm{~g} \mathrm{ha}^{-1} \mathrm{~h}^{-1}$ after the basal $\mathrm{N}$ applications in 2014 and 2015, respectively, while only 100-130 $\mathrm{g} \mathrm{ha}^{-1} \mathrm{~h}^{-1}$ were observed in the $\mathrm{N} 2$ and $\mathrm{N} 3$ treatments. After the $\mathrm{T}_{\mathrm{V} 8}-\mathrm{N}$ application, the mean rates of $\mathrm{NH}_{3}$ volatilization from the $\mathrm{N} 2$ treatment were 18.8 and $26.5 \mathrm{~g} \mathrm{ha}^{-1} \mathrm{~h}^{-1}$ in 2014 and 2015, respectively, which were significantly higher than those from the N3 treatment $\left(10.4 \mathrm{~g} \mathrm{ha}^{-1} \mathrm{~h}^{-1}\right.$ in 2014 and $11.8 \mathrm{~g} \mathrm{ha}^{-1} \mathrm{~h}^{-1}$ in 2015). A small emissions peak emerged in the $\mathrm{N} 3$ treatment when $\mathrm{T}_{\mathrm{R} 1}$ $\mathrm{N}$ was applied, with the highest volatilization rates of $37.5 \mathrm{~g} \mathrm{ha}^{-1} \mathrm{~h}^{-1}$ in 2014 and $77.5 \mathrm{~g} \mathrm{ha}^{-1} \mathrm{~h}^{-1}$ in 2015 . 

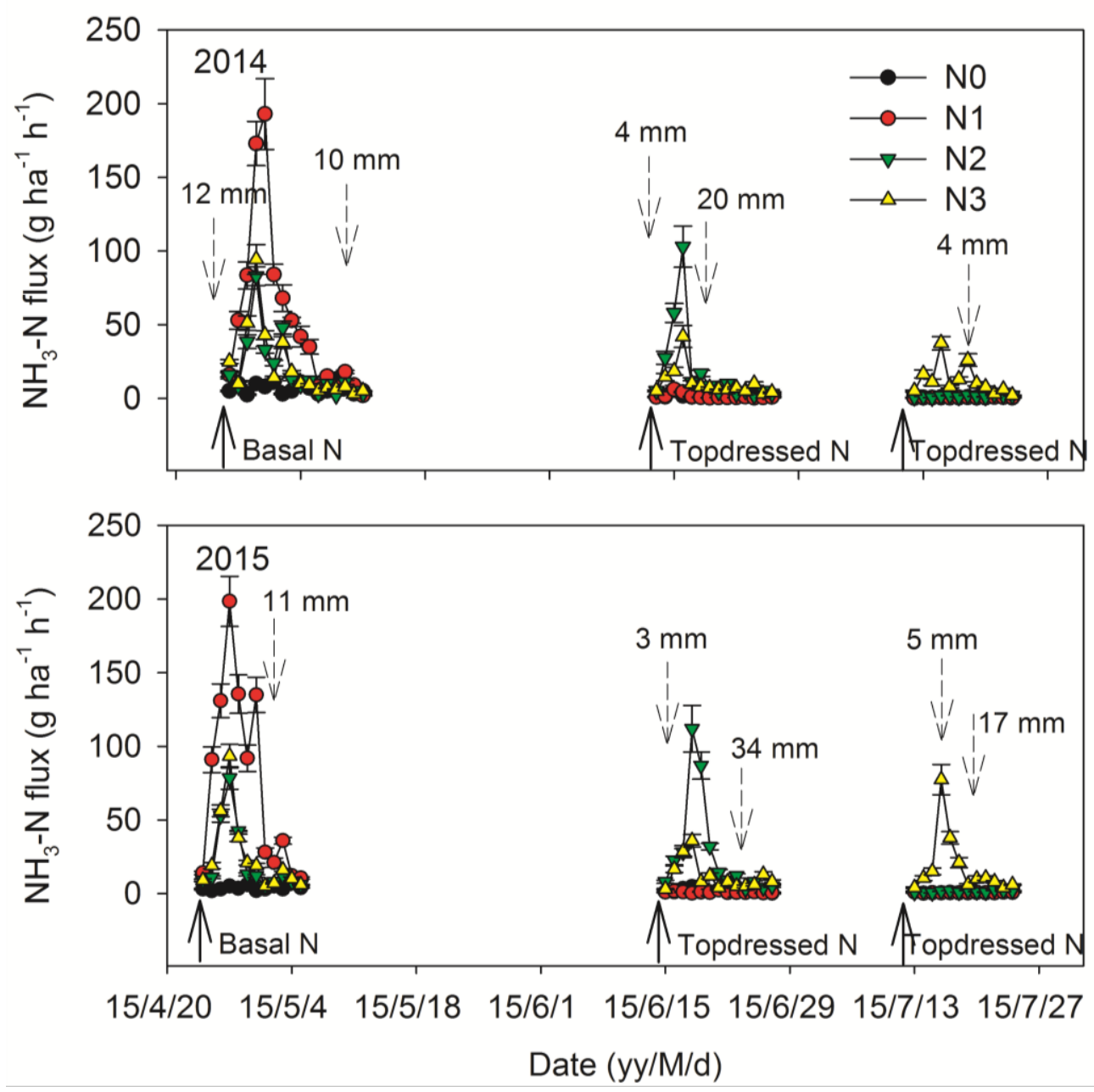

Figure 4. $\mathrm{NH}_{3}$ volatilization fluxes after the application of basal and topdressed $\mathrm{N}$ in 2014 and 2015. Bars denote standard deviations of $\mathrm{NH}_{3}$ fluxes on three replicate plots

The total $\mathrm{NH}_{3}$ volatilization and fertilizer-induced emission (FIE) are shown in Table 1. The total $\mathrm{NH}_{3}$ volatilizations under different $\mathrm{N}$ split applications were 13.5$20.4 \mathrm{~kg} \mathrm{ha}^{-1}$ and 14.2-21.5 kg ha-1 in 2014 and 2015, respectively, accounting for $6.0 \%$ $9.1 \%$ and $6.3 \%-9.6 \%$ of the total $\mathrm{N}$ application rates, respectively. The amount of $\mathrm{NH}_{3}$ volatilization increased with increasing $\mathrm{N}$ levels applied after the basal or topdressed $\mathrm{N}$ applications. Compared to the single $\mathrm{N}$ application (N1), $\mathrm{N}$ applications with two or three splits significantly reduced the $\mathrm{NH}_{3}$ volatilization losses by $30.5 \%$. The FIE of $\mathrm{NH}_{3}$ from basal $\mathrm{N}$ was $7.6 \%$ (averaged over two years), which was significantly higher than that from topdressed $\mathrm{N}(5.2 \%)$ in the $\mathrm{N} 2$ treatment. For the $\mathrm{N} 3$ treatment, a higher FIE of $\mathrm{NH}_{3}$ was measured from basal $\mathrm{N}(8.4 \%)$ than from topdressed $\mathrm{N}(5.7 \%)$.

The $\mathrm{NH}_{3}$ volatilization flux was significantly and positively correlated with the soil $\mathrm{NH}_{4}{ }^{+}-\mathrm{N}$ content, while no significant correlation was observed among the $\mathrm{NH}_{3}$ volatilization flux, soil WFPS and temperature (Table 2).

\section{Grain yield and $N$ recovery efficiency}

Compared with the $\mathrm{N} 0$ treatment, the $\mathrm{N}$ fertilizer application treatments significantly increased the grain yield of maize, varying from 12.4 to $13.3 \mathrm{t} \mathrm{ha}^{-1}$ under different $\mathrm{N}$ 
split applications over two years. The mean yields in the two years were 13.2 and $13.4 \mathrm{t} \mathrm{ha}^{-1}$ in the $\mathrm{N} 2$ and N3 treatments, respectively, which were significantly higher than that of in the treatment $\mathrm{N} 1$ of $12.4 \mathrm{t} \mathrm{ha}^{-1}$. The total $\mathrm{N}$ uptake varied from 193.9 to $238.5 \mathrm{~kg} \mathrm{ha}^{-1}$ in the fertilized treatments, and split $\mathrm{N}$ application significantly increased the total $\mathrm{N}$ uptake. The average NRE across two years was $47.3 \%, 58.8 \%$ and $67.1 \%$ in the N1, N2 and N3 treatments, respectively. In comparison to N1, applying $\mathrm{N}$ with two or three splits increased the NRE significantly.

Table 1. Accumulated $\mathrm{NH}_{3}$ volatilization and fertilizer induced emission (FIE) from basal and topdressed $N$ fertilizer

\begin{tabular}{|c|c|c|c|c|c|c|}
\hline \multirow{2}{*}{\multicolumn{2}{|c|}{ Treatments }} & \multirow{2}{*}{$\begin{array}{c}\text { N rate } \\
\left(\mathrm{kg} \mathrm{ha}^{-1}\right)\end{array}$} & \multicolumn{2}{|c|}{$\begin{array}{c}\text { Total } \mathrm{NH}_{3} \text { volatilization } \\
\left(\mathrm{kg} \mathrm{ha}^{-1}\right)\end{array}$} & \multicolumn{2}{|c|}{ Fertilizer-induced emission $(\%)$} \\
\hline & & & 2014 & 2015 & 2014 & 2015 \\
\hline \multicolumn{2}{|c|}{ N1 } & 225 & $20.4 \mathrm{aA}$ & $21.5 \mathrm{aA}$ & $9.1 \mathrm{aA}$ & $9.6 \mathrm{aA}$ \\
\hline \multirow{3}{*}{$\mathrm{N} 2$} & B & 90 & $7.1 \mathrm{~b}$ & $6.5 \mathrm{~b}$ & $7.9 \mathrm{a}$ & $7.2 \mathrm{~b}$ \\
\hline & $\mathrm{T}_{\mathrm{V} 8}$ & 135 & $6.4 \mathrm{~b}$ & $7.7 \mathrm{~b}$ & $4.7 \mathrm{~b}$ & $5.7 \mathrm{c}$ \\
\hline & Total & 225 & $13.5 \mathrm{~B}$ & $14.2 \mathrm{~B}$ & $6.0 \mathrm{~B}$ & $6.3 \mathrm{~B}$ \\
\hline \multirow{4}{*}{ N3 } & B & 90 & $7.8 \mathrm{~b}$ & $7.3 \mathrm{~b}$ & $8.6 \mathrm{a}$ & $8.1 \mathrm{~b}$ \\
\hline & $\mathrm{T}_{\mathrm{V} 8}$ & 67.5 & $3.4 \mathrm{c}$ & $3.5 \mathrm{c}$ & $5.0 \mathrm{~b}$ & $5.2 \mathrm{c}$ \\
\hline & $\mathrm{T}_{\mathrm{R} 1}$ & 67.5 & $3.6 \mathrm{c}$ & $4.9 \mathrm{c}$ & $5.4 \mathrm{~b}$ & $7.3 \mathrm{~b}$ \\
\hline & Total & 225 & $14.8 \mathrm{~B}$ & $15.7 \mathrm{~B}$ & $6.6 \mathrm{~B}$ & $7.0 \mathrm{~B}$ \\
\hline
\end{tabular}

Different lowercase letters within a column indicate significant differences $(\mathrm{p}<0.05)$. Different capital letters within a column indicate significant differences $(\mathrm{p}<0.05)$. B denotes basal $\mathrm{N} ; \mathrm{T}_{\mathrm{V} 8}$ and $\mathrm{T}_{\mathrm{R} 1}$ denote topdressed $\mathrm{N}$ at the eight-leaf stage and the silking stage, respectively

Table 2. The relationship between $\mathrm{NH}_{3}$ volatilization flux and soil properties

\begin{tabular}{c|c|c|c}
\hline & Soil $\mathbf{N H}_{4}{ }^{+}-\mathbf{N}$ & WFPS & Soil temperature \\
\hline $\mathrm{NH}_{3}$ flux & $0.288^{* *}$ & 0.021 & -0.089 \\
\hline
\end{tabular}

***Correlation is significant at the 0.01 level

\section{Discussion}

Urea applied to soil will be rapidly hydrolyzed into ammonium nitrogen at appropriate temperature and humidity and then easily converted into $\mathrm{NH}_{3}$ volatilization loss ( $\mathrm{Li}$ et al., 2018). The total cumulative $\mathrm{NH}_{3}$ loss under different $\mathrm{N}$ split applications ranged from 6.2 to $9.4 \%$ of the applied $\mathrm{N}$ in this study (Table 1), which were slightly lower than the emissions factor of $10 \%$ of applied N advocated by the IPCC (2007). A lower FIE of less than $2.5 \%$ has also been reported by another study on the Loess Plateau in rain-fed winter wheat field (Yang et al., 2015). Cai et al. (2002) found that the $\mathrm{NH}_{3}$ volatilization losses range from 11 to $48 \%$ of the applied $\mathrm{N}$ to maize. The lower $\mathrm{NH}_{3}$ losses in the present study than in Cai et al. (2002) may be attributed to the application method of $\mathrm{N}$ fertilizer. In this study, basal $\mathrm{N}$ was broadcast on the surface and then was mixed into soil; for topdressed $\mathrm{N}, \mathrm{N}$ fertilizer was applied in a band in the middle of the no-film rows at a depth of $5 \mathrm{~cm} . \mathrm{NH}_{3}$ volatilization losses of $\mathrm{N}$ fertilizer are closely related to the application technique and $\mathrm{N}$ rate (Sommer et al., 2003; Zhao et al., 2009). In comparison to surface application, deep placement of $\mathrm{N}$ fertilizer could 
reduce $\mathrm{NH}_{3}$ losses substantially (Zeng et al., 2016). Rochette et al. (2013) reported that $\mathrm{NH}_{3}$ volatilization losses were $50 \%$ of applied $\mathrm{N}$ when urea was banded at the surface and incorporation of the band decreased emissions by an average of $7 \% \mathrm{~cm}^{-1}$. Pan et al. (2016) also found that in comparison to surface application, deep placement significantly decreased $\mathrm{NH}_{3}$ volatilization through the incorporation of fertilizer at $54.7 \%$.

A previous study reported that a split applications of $\mathrm{N}$ fertilizer did not affect $\mathrm{NH}_{3}$ volatilization, regardless of splitting frequency (Pan et al., 2016). In our study, applying $\mathrm{N}$ with two or three splits significantly decreased $\mathrm{NH}_{3}$ volatilization by $30.5 \%$ over two years, and the FIE from topdressed $\mathrm{N}$ was significantly lower than that from basal $\mathrm{N}$ (Table 1). One possible reason for this discrepancy is the different application method with basal and topdressed $\mathrm{N}$, as described above. Basal $\mathrm{N}$ was broadcast on the surface and then mixed with the $0-15 \mathrm{~cm}$ soil; however, some of the $\mathrm{N}$ fertilizer was still exposed on the soil surface, increasing the risk of $\mathrm{NH}_{3}$ losses compared to that with topdressed $\mathrm{N}$. In addition, $\mathrm{N}$ losses through $\mathrm{NH}_{3}$ volatilization increase with an increasing rate of $\mathrm{N}$ application in soils (Tian et al., 2001; Zhao et al., 2009), and previous studies have shown that the $\mathrm{NH}_{3}$ emissions response to increasing $\mathrm{N}$ input is exponential rather than linear (Ma et al., 2010). In the present study, all $\mathrm{N}$ fertilizer was applied as basal dressing in treatment $\mathrm{N} 1$, which led to large amounts of $\mathrm{NH}_{3}$ volatilization.

$\mathrm{NH}_{3}$ volatilization is a physical process that is mainly influenced by the concentration of $\mathrm{NH}_{4}{ }^{+}-\mathrm{N}$ in the soil solution and by the resistance to $\mathrm{NH}_{3}$ movement from the soil matrix (Sommer et al., 2004). Rochette et al. (2013) found cumulative losses increased exponentially with increasing maximum $\mathrm{NH}_{4}{ }^{+}-\mathrm{N}$ measured in the surface soil during the experiment. Consistent with previous reports, significant and positive correlations were observed between $\mathrm{NH}_{3}$ volatilization flux and soil $\mathrm{NH}_{4}{ }^{+}-\mathrm{N}$ contents in this study (Table 2). Soil temperature and moisture are two other important factors affecting $\mathrm{NH}_{3}$ volatilization. Fan et al. (2011) reported that the cumulative $\mathrm{NH}_{3}$ volatilization loss increased by 1.6 fold in sandy soil when the temperature increased from 20 to $30{ }^{\circ} \mathrm{C}$. A study in the wheat growing season showed that soil temperature has positive effects on $\mathrm{NH}_{3}$ fluxes during Oct-Dec but has negative effects during Feb.-May (Yang et al., 2015). However, no significant correlations were observed between $\mathrm{NH}_{3}$ flux and soil temperature in the present study. This difference could be explained by the influence of precipitation events on the soil temperature and $\mathrm{NH}_{3}$ volatilization flux. In some cases, high $\mathrm{NH}_{3}$ emissions occurred following precipitation events when the soil temperature was relatively low. Soil moisture had significant positive effects on $\mathrm{NH}_{3}$ fluxes, which could explain 7.3-19.7\% of the variation in the $\mathrm{NH}_{3}$ fluxes (Yang et al., 2015). Bosch-Serra et al. (2014) found that $\mathrm{NH}_{3}$ volatilization was significantly reduced when the WFPS in the $0-30 \mathrm{~cm}$ soil layer was less than $56 \%$. In this study, no significant correlations were observed between the $\mathrm{NH}_{3}$ flux and soil WFPS. This result may be attributed to the different effects of precipitation amount on $\mathrm{NH}_{3}$ fluxes. Previous studies have reported that the magnitude of $\mathrm{NH}_{3}$ losses was largely influenced by small temporal differences in the weather and initial soil moisture content (Engel et al., 2011; Turner et al., 2012). The largest losses (30-44\% of applied N) occurred after urea was applied to high-water content soil surfaces, followed by a period of slow drying with little or no precipitation (Engel et al., 2011). Light precipitation and high soil moisture would increase $\mathrm{NH}_{3}$ volatilization risk by promoting urea hydrolysis, while heavy precipitation may effectively mitigate $\mathrm{NH}_{3}$ losses by leaching 
unhydrolyzed urea into the soil profile (Holcomb et al., 2011). In this study, the $\mathrm{NH}_{3}$ flux increased sharply following slight precipitation events of $3 \mathrm{~mm}$ and $5 \mathrm{~mm}$ after topdressed $\mathrm{N}$ was applied at the V8 and R1 stages, respectively, in 2015. We also observed that the $\mathrm{NH}_{3}$ flux was restrained rapidly by heavy precipitation of $20 \mathrm{~mm}$ after the application of topdressed $\mathrm{N}$ at the V8 stage in 2014 (Fig. 4).

Adjusting the application timing of $\mathrm{N}$ fertilizer and improving temporal synchronicity between crop- $\mathrm{N}$ demand and soil-N availability is a key strategy for improving the NRE (Ribaudo et al., 2011). In the present study, higher grain yields, total $\mathrm{N}$ uptake, and NRE were observed from the plots under $\mathrm{N}$ split applications than in the other plots (Table 3). Similar to our results, Shi et al. (2012) also found that the grain yield and NRE increased significantly when $\mathrm{N}$ fertilizer application was divided into an appropriate ratio of basal and topdressed N. Yi et al. (2008) reported that the NRE increased by more than 2 fold when $\mathrm{N}$ was applied with splits of 1:1 compared with a split of 2:1 of basal to topdressed $\mathrm{N}$. This result may be attributed to the lower $\mathrm{N}$ demand in the early growth stage of maize and the increased risk of leaching from a large amount of $\mathrm{N}$ fertilizer input. Kettering et al. (2013) indicated that applying fertilizer $\mathrm{N}$ with 3-4 splits according to a plant's $\mathrm{N}$ needs could reduce $\mathrm{N}$ leaching and increase the NRE.

Table 3. Grain yield, total $N$ uptake and $N$ recovery efficiency

\begin{tabular}{c|c|c|c|c|c|c}
\hline \multirow{2}{*}{ Treatments } & \multicolumn{2}{|c|}{ Grain Yield $\left(\mathbf{t ~ h a}^{\mathbf{- 1}}\right)$} & \multicolumn{2}{c|}{ Total N uptake $\left(\mathbf{k g ~ h a}^{\mathbf{- 1}}\right)$} & \multicolumn{2}{c}{ NRE (\%) } \\
\cline { 2 - 7 } & $\mathbf{2 0 1 4}$ & $\mathbf{2 0 1 5}$ & $\mathbf{2 0 1 4}$ & $\mathbf{2 0 1 5}$ & $\mathbf{2 0 1 4}$ & $\mathbf{2 0 1 5}$ \\
\hline N0 & $8.6 \mathrm{c}$ & $3.6 \mathrm{c}$ & $125.2 \mathrm{~d}$ & $50.1 \mathrm{~d}$ & & \\
N1 & $12.7 \mathrm{~b}$ & $12.1 \mathrm{~b}$ & $218.7 \mathrm{c}$ & $169.1 \mathrm{c}$ & $41.6 \mathrm{c}$ & $52.9 \mathrm{c}$ \\
N2 & $13.3 \mathrm{a}$ & $13.0 \mathrm{a}$ & $242.8 \mathrm{~b}$ & $197.0 \mathrm{~b}$ & $52.3 \mathrm{~b}$ & $65.3 \mathrm{~b}$ \\
N3 & $13.5 \mathrm{a}$ & $13.2 \mathrm{a}$ & $255.0 \mathrm{a}$ & $221.9 \mathrm{a}$ & $57.7 \mathrm{a}$ & $76.4 \mathrm{a}$ \\
\hline
\end{tabular}

Different lowercase letters within a column indicate significant differences $(\mathrm{p}<0.05)$

\section{Conclusions}

$\mathrm{NH}_{3}$ flux was positively correlated with soil $\mathrm{NH}_{4}{ }^{+}-\mathrm{N}$ content and was greatly affected by precipitation events. Applying $\mathrm{N}$ with two or three splits significantly increased the grain yield, total $\mathrm{N}$ uptake, and NRE of maize and significantly reduced $\mathrm{NH}_{3}$ volatilization losses. The coupling effect of $\mathrm{N}$ fertilizer application and precipitation on $\mathrm{NH}_{3}$ volatilization should be further investigated in the future.

Acknowledgements. This research was financially supported by the Ministry of Science and Technology of China (2015CB150402), National Key Research and Development Plan (2017YFD0200100, 2017YFD0201807), National Natural Science Foundation of China (41601308, 41601310).

\section{REFERENCES}

[1] Behera, S. N., Sharma, M., Aneja, V. P., Balasubramanian, R. (2013): Ammonia in the atmosphere: a review on emission sources, atmospheric chemistry and deposition on terrestrial bodies. - Environmental Science and Pollution Research 20(11): 8092-8131.

[2] Black, A., Sherlock, R., Smith, N. (1987): Effect of urea granule size on ammonia volatilization from surface-applied urea. - Fertilizer Research 11(1): 87-96. 
[3] Bosch-Serra, À. D., Yagüe, M. R., Teira-Esmatges, M. R. (2014): Ammonia emissions from different fertilizing strategies in Mediterranean rainfed winter cereals. Atmospheric Environment 84: 204-212.

[4] Boyer, E. W., Goodale, C. L., Jaworski, N. A., Howarth, R. W. (2002): Anthropogenic Nitrogen Sources and Relationships to Riverine Nitrogen Export in the Northeastern U.S.A. - In: Boyer, E. W., Howarth, R. W. (eds.) The Nitrogen Cycle at Regional to Global Scales. Springer, Dordrecht, pp. 137-169.

[5] Cai, G. X., Chen, D. L., Ding, H., Pacholski, A., Fan, X. H., Zhu, Z. L. (2002): Nitrogen losses from fertilizers applied to maize, wheat and rice in the North China Plain. Nutrient Cycling in Agroecosystems 63(2): 187-195.

[6] Chen, X., Cui, Z., Fan, M., Vitousek, P., Zhao, M., Ma, W., Wang, Z., Zhang, W., Yan, X., Yang, J., Deng, X., Gao, Q., Zhang, Q., Guo, S., Ren, J., Li, S., Ye, Y., Wang, Z., Huang, J., Tang, Q., Sun, Y., Peng, X., Zhang, J., He, M., Zhu, Y., Xue, J., Wang, G., Wu, L., An, N., Wu, L., Ma, L., Zhang, W., Zhang, F. (2014): Producing more grain with lower environmental costs. - Nature 514(7523): 486-489.

[7] Cui, Z. L., Zhang, F. S., Chen, X. P., Miao, Y. X., Li, J. L., Shi, L. W., Xu, J. F., Youliang, Y. L., Liu, C. S., Yang, Z. P., Qiang, Z., Huang, S. M., Bao, D. J. (2008): Onfarm evaluation of an in-season nitrogen management strategy based on soil $\mathrm{N}$-min test. Field Crops Research 105(1-2): 48-55.

[8] Engel, R., Jones, C., Wallander, R. (2011): Ammonia volatilization from urea and mitigation by NBPT following surface application to cold soils. - Soil Science Society of America Journal 75: 2348-2357.

[9] Fan, X. H., Li, Y. C., Alva, A. K. (2011): Effects of temperature and soil type on ammonia volatilization from slow-release nitrogen fertilizers. - Communications in Soil Science and Plant Analysis 42(10): 1111-1122.

[10] Ferm, M. (1998): Atmospheric ammonia and ammonium transport in Europe and critical loads: a review. - Nutrient Cycling in Agroecosystems 51(1): 5-17.

[11] Gong, Z., Zhang, G., Chen, Z. (2007): Pedogenesis and Soil Taxonomy (in Chinese). Science Press Publishing, Beijing.

[12] Holcomb, J. C., Sullivan, D. M., Horneck, D. A., Clough, G. H. (2011): Effect of Irrigation Rate on Ammonia Volatilization. - Soil Science Society of America Journal 75: 2341-2347.

[13] Kettering, J., Ruidisch, M., Gaviria, C., Ok, Y. S., Kuzyakov, Y. (2013): Fate of fertilizer ${ }^{15} \mathrm{~N}$ in intensive ridge cultivation with plastic mulching under a monsoon climate. Nutrient Cycling in Agroecosystems 95(1): 57-72.

[14] López-Bellido, L., López-Bellido, R. J., Redondo, R. (2005): Nitrogen efficiency in wheat under rainfed Mediterranean conditions as affected by split nitrogen application. Field Crops Research 94(1): 86-97.

[15] Li, F.-M., Wang, J., Xu, J.-Z., Xu, H.-L. (2004): Productivity and soil response to plastic film mulching durations for spring wheat on entisols in the semiarid Loess Plateau of China. - Soil and Tillage Research 78(1): 9-20.

[16] Li, M., Wang, Y., Adeli, A., Yan, H. (2018): Effects of application methods and urea rates on ammonia volatilization, yields and fine root biomass of alfalfa. - Field Crops Research 218: 115-125.

[17] Liu, T. Q., Fan, D. J., Zhang, X. X., Chen, J., Li, C. F., Cao, C. G. (2015): Deep placement of nitrogen fertilizers reduces ammonia volatilization and increases nitrogen utilization efficiency in no-tillage paddy fields in central China. - Field Crops Research 184: 80-90.

[18] Ma, B. L., Wu, T. Y., Tremblay, N., Deen, W., McLaughlin, N. B., Morrison, M. J., Stewart, G. (2010): On-farm assessment of the amount and timing of nitrogen fertilizer on ammonia volatilization. - Agronomy Journal 102: 134-144. 
[19] Ni, K., Pacholski, A., Kage, H. (2014): Ammonia volatilization after application of urea to winter wheat over 3 years affected by novel urease and nitrification inhibitors. Agriculture, Ecosystems \& Environment 197: 184-194.

[20] Pacholski, A., Cai, G., Nieder, R., Richter, J., Fan, X., Zhu, Z., Roelcke, M. (2006): Calibration of a simple method for determining ammonia volatilization in the field comparative measurements in Henan Province, China. - Nutrient Cycling in Agroecosystems 74(3): 259-273.

[21] Pan, B., Lam, S. K., Mosier, A., Luo, Y., Chen, D. (2016): Ammonia volatilization from synthetic fertilizers and its mitigation strategies: a global synthesis. - Agriculture, Ecosystems \& Environment 232: 283-289.

[22] Paulot, F., Jacob, D. J., Pinder, R. W., Bash, J. O., Travis, K., Henze, D. K. (2014): Ammonia emissions in the United States, European Union, and China derived by highresolution inversion of ammonium wet deposition data: interpretation with a new agricultural emissions inventory (MASAGE_NH $\mathrm{NH}_{3}$. - Journal of Geophysical Research: Atmospheres 119(7): 4343-4364.

[23] Ribaudo, M., Hansen, L., Livingston, M., Mosheim, R., Williamson, J., Delgado, J. (2011): Nitrogen in agricultural systems: Implications for conservation policy. - USDAERS Economic Research Report Number 127, Washington, DC.

[24] Rochette, P., Angers, D. A., Chantigny, M. H., Gasser, M.-O., MacDonald, J. D., Pelster, D. E., Bertrand, N. (2013): Ammonia volatilization and nitrogen retention: how deep to incorporate urea? - Journal of Environmental Quality 42: 1635-1642.

[25] Scharf, P. C., Wiebold, W. J., Lory, J. A. (2002): Corn Yield Response to Nitrogen Fertilizer Timing and Deficiency Level. - Agronomy Journal 94(3): 435-441.

[26] Shi, Z., Jing, Q., Cai, J., Jiang, D., Cao, W., Dai, T. (2012): The fates of 15N fertilizer in relation to root distributions of winter wheat under different $\mathrm{N}$ splits. - European Journal of Agronomy 40: 86-93.

[27] Soares, J. R., Cantarella, H., Menegale, M. L. d. C. (2012): Ammonia volatilization losses from surface-applied urea with urease and nitrification inhibitors. - Soil Biology and Biochemistry 52: 82-89.

[28] Sommer, S. G., Génermont, S., Cellier, P., Hutchings, N., Olesen, J. E., Morvan, T. (2003): Processes controlling ammonia emission from livestock slurry in the field. European Journal of Agronomy 19(4): 465-486.

[29] Sommer, S. G., Schjoerring, J. K., Denmead, O. T. (2004): Ammonia emission from mineral fertilizers and fertilized crops. - Advances in Agronomy 82: 557-622.

[30] Sutton, M. A., Erisman, J. W., Dentener, F., Möller, D. (2008): Ammonia in the environment: From ancient times to the present. - Environmental Pollution 156(3): 583604.

[31] Sutton, M. A., Reis, S., Riddick Stuart, N., Dragosits, U., Nemitz, E., Theobald Mark, R., Tang, Y. S., Braban Christine, F., Vieno, M., Dore Anthony, J., Mitchell Robert, F., Wanless, S., Daunt, F., Fowler, D., Blackall Trevor, D., Milford, C., Flechard Chris, R., Loubet, B., Massad, R., Cellier, P., Personne, E., Coheur Pierre, F., Clarisse, L., Van Damme, M., Ngadi, Y., Clerbaux, C., Skjøth Carsten, A., Geels, C., Hertel, O., Wichink Kruit Roy, J., Pinder Robert, W., Bash Jesse, O., Walker John, T., Simpson, D., Horváth, L., Misselbrook Tom, H., Bleeker, A., Dentener, F., de Vries, W. (2013): Towards a climate-dependent paradigm of ammonia emission and deposition. - Philosophical Transactions of the Royal Society B: Biological Sciences 368(1621): 20130166.

[32] Tian, G., Cai, Z., Cao, J., Li, X. (2001): Factors affecting ammonia volatilisation from a rice-wheat rotation system. - Chemosphere 42(2): 123-129.

[33] Turner, D. A., Edis, R. E., Chen, D., Freney, J. R., Denmead, O. T. (2012): Ammonia volatilization from nitrogen fertilizers applied to cereals in two cropping areas of southern Australia. - Nutrient Cycling in Agroecosystems 93(2): 113-126. 
[34] Wang, S., Luo, S., Li, X., Yue, S., Shen, Y., Li, S. (2016): Effect of split application of nitrogen on nitrous oxide emissions from plastic mulching maize in the semiarid Loess Plateau. - Agriculture, Ecosystems \& Environment 220: 21-27.

[35] Wolf, U., Fuß, R., Höppner, F., Flessa, H. (2014): Contribution of $\mathrm{N}_{2} \mathrm{O}$ and $\mathrm{NH}_{3}$ to total greenhouse gas emission from fertilization: results from a sandy soil fertilized with nitrate and biogas digestate with and without nitrification inhibitor. - Nutrient Cycling in Agroecosystems 100(1): 121-134.

[36] Yang, Q., Liu, P., Dong, S., Zhang, J., Zhao, B. (2019): Effects of fertilizer type and rate on summer maize grain yield and ammonia volatilization loss in northern China. Journal of Soils and Sediments 19(5): 2200-2211.

[37] Yang, Y., Zhou, C., Li, N., Han, K., Meng, Y., Tian, X., Wang, L. (2015): Effects of conservation tillage practices on ammonia emissions from Loess Plateau rain-fed winter wheat fields. - Atmospheric Environment 104: 59-68.

[38] Yi, Z., Wang, P., Hong, B., Lu, L., Yu, G. (2008): Effect of base $\mathrm{N}$ to dress $\mathrm{N}$ ratio on water and nitrogen utilization, growth of summer maize in North China Plain. II. Nitrogen accumulation and translocation of summer maize and dynamics of soil inorganic N. - Chinese Journal of Eco-Agriculture 16(1): 86-90.

[39] Zeng, J., Liu, X., Song, L., Lin, X., Zhang, H., Shen, C., Chu, H. (2016): Nitrogen fertilization directly affects soil bacterial diversity and indirectly affects bacterial community composition. - Soil Biology and Biochemistry 92: 41-49.

[40] Zhang, Y., Luan, S., Chen, L., Shao, M. (2011): Estimating the volatilization of ammonia from synthetic nitrogenous fertilizers used in China. - Journal of Environmental Management 92(3): 480-493.

[41] Zhao, X., Xie, Y. X., Xiong, Z. Q., Yan, X. Y., Xing, G. X., Zhu, Z. L. (2009): Nitrogen fate and environmental consequence in paddy soil under rice-wheat rotation in the Taihu Lake region, China. - Plant and Soil 319(1-2): 225-234. 